\title{
Dose reduction of epoetin-alpha in the prevention of chemotherapy-induced anaemia
}

\author{
François Lüthi • Miklos Pless • Serge Leyvraz • \\ Beat Biedermann • Emilie Müller • Richard Hermann • \\ Christian Monnerat
}

Received: 25 January 2009 /Accepted: 26 October 2009/Published online: 17 November 2009

(C) Springer-Verlag 2009

\begin{abstract}
Introduction Anaemia during chemotherapy is often left untreated. Erythropoiesis-stimulating agents are frequently used to treat overt anaemia. Their prophylactic use, however, remains controversial and raises concerns about cost-effectiveness. Therefore, we assessed the efficacy of a dose-reduction schedule in anaemia prophylaxis.

Materials and methods The study included patients with untreated solid tumours about to receive platinum-based chemotherapy and had haemoglobin (Hb) levels $\geq 11 \mathrm{~g} / \mathrm{dL}$. Epoetin- $\alpha$ was administered at a dose level of $3 \times 10,000 \mathrm{U}$ weekly as soon as $\mathrm{Hb}$ descended to $<13 \mathrm{~g} / \mathrm{dL}$. Dose reductions to $3 \times 4,000 \mathrm{U}$ and $3 \times 2,000 \mathrm{U}$ weekly were planned in 4-week intervals if $\mathrm{Hb}$ stabilised in the range of $11-13 \mathrm{~g} / \mathrm{dL}$. Upon ascending to $\geq 13 \mathrm{~g} / \mathrm{dL}$, epoetin was discontinued. Iron supplements of $100 \mathrm{mg}$ intravenous doses were given weekly. Of 37 patients who enrolled, 33 could be evaluated.

Results and discussion Their median $\mathrm{Hb}$ level was 13.7 $(10.9-16.2) \mathrm{g} / \mathrm{dL}$ at baseline and descended to 11.0 $(7.4-13.8) \mathrm{g} / \mathrm{dL}$ by the end of chemotherapy. Anaemia $(\mathrm{Hb}<10 \mathrm{~g} / \mathrm{dL})$ was prevented in 24 patients $(73 \%)$. The mean dose requirement for epoetin- $\alpha$ was $3 \times 5,866 \mathrm{U}$ per week per patient, representing a dose reduction of $41 \%$.
\end{abstract}

François Lüthi and Miklos Pless contributed equally to the work.

F. Lüthi $\cdot$ S. Leyvraz $(\bowtie) \cdot$ C. Monnerat

Centre Pluridisciplinaire d'Oncologie,

University Hospital-CHUV BH06,

Rue du Bugnon 46,

1011 Lausanne, Switzerland

e-mail: Serge.Leyvraz@chuv.ch

M. Pless $\cdot$ B. Biedermann $\cdot$ E. Müller $\cdot$ R. Hermann Department of Oncology, University of Basel, Basel, Switzerland
Treatment failed in nine patients $(27 \%)$, in part due to epoetin- $\alpha$ resistance in four $(12 \%)$ and blood transfusion in three $(9 \%)$ patients.

Conclusion Dose reduction was as effective as fixed doses in anaemia prophylaxis but reduced the amount of prescribed epoetin substantially.

Keywords Anaemia E Epoetin · Chemotherapy Prevention

\section{Introduction}

Anaemia is commonly observed in cancer patients. The prevalence is $39 \%$ at the time of diagnosis. During chemotherapy, the incidence has been shown to reach $63 \%$ [28] and increases with the number of chemotherapy cycles. Incidence of anaemia is also higher in lung (71\%) or gynaecological (65\%) cancers [22]. Management of anaemia, including the use of erythropoietin proteins, varies widely. The majority of cases (61\%) are left untreated. Only $17 \%$ of cases are treated with epoetin and $15 \%$ with blood transfusions.

Major oncological societies have issued guidelines for the management of anaemia, notably including the American Society of Clinical Oncology [33], the National Comprehensive Cancer Network [1], and the European Organization of Research and Treatment of Cancer [2, 11, 35]. Treatment with erythropoiesisstimulating agents (ESA's) is recommended for anaemic patients $(\mathrm{Hb}<10 \mathrm{~g} / \mathrm{dL})$ on chemotherapy and/or radiotherapy. For patients with declining $\mathrm{Hb}$ levels but less severe anaemia $(\mathrm{Hb}<12 \mathrm{~g} / \mathrm{dL})$, clinical circumstances such as $\mathrm{Hb}$ levels prior to cancer treatment shall be considered before initiation of ESA's. Recent guideline updates recommend $\mathrm{Hb}$ target levels of $12 \mathrm{~g} / \mathrm{dL}$ with a view to improve quality 
of life and minimise the risk of blood transfusion. Despite these recommendations, half of all patients affected do not receive treatment, leading to impaired quality of life and potentially decreased survival [12, 27, 28, 43].

Furthermore, the management of anaemia focuses mainly on the treatment of cancer or chemotherapyinduced anaemia and only to a lesser extent on the prevention of chemotherapy-induced anaemia. However, there is some evidence from unblinded studies that immediate versus delayed initiation of erythropoietinstimulating agents at a $\mathrm{Hb}$ threshold can reduce the transfusion rate and improve scores on physical and functional well-being [17, 33, 39].

The usual dose regimen for epoetin- $\alpha$ is either $10,000 \mathrm{U}$ $(150 \mathrm{U} / \mathrm{kg}$ ) administered three times a week or $40,000 \mathrm{U}$ once a week. Longer dosing intervals (every 2 or 3 weeks) using modified ESA's with longer half life are equally efficacious [37]. ESA's administration should be temporarily discontinued if target values are exceeded but should be reinforced in the absence of a $\mathrm{Hb}$ response. Findings from several randomised studies and meta-analyses demonstrate that ESA's are capable of both raising $\mathrm{Hb}$ levels by $\geq 2 \mathrm{~g} / \mathrm{dL}$ in $53 \%$ of patients and reducing the risk of blood transfusions from $23-65 \%$ to $9-36 \%$ [26, 42]. These outcomes are associated with improved health-related quality of life and reduced symptoms after controlling for clinical and demographic aspects $[8,10,13,18,21,31,34,36]$.

Concerns on the use of ESA's have been raised of an increased risk of venous thromboembolic events (VTEs) and mortality [7]. The higher incidence of VTEs might be due to a high haematocrit and elevated viscosity and therefore controlled by limiting the target $\mathrm{Hb}$ levels [38]. A recent meta-analysis on individual patient data estimated a $17 \%$ increase in mortality rate in cancer patients [9]. Recent reports also suggest that the erythropoietin receptor on cancer cells may play a role in promoting cell proliferation and survival $[3,24,25]$. These findings emphasise the need to monitor $\mathrm{Hb}$ levels closely and also to use the lowest dose of ESA's required to maintain the target level.

ESA's also impose a substantial burden on hospital budgets and the entire healthcare systems. Use of these agents has been estimated to account for over $10 \%$ of total expenses for cancer care [19, 29]. Therefore, any strategy that enables better control of epoetin administration would be highly welcomed. Our goal is to develop a strategy that will reduce the dose requirements for ESA's to the lowest level while still offering effective prophylaxis of chemotherapy-induced anaemia.

The objective of the present study was to evaluate the efficacy of a dose-reduction schedule for epoetin- $\alpha$ administered in conjunction with an intravenous iron supplement to prevent anaemia (defined as $\mathrm{Hb}<10 \mathrm{~g} / \mathrm{dL}$ ) during platinum-based chemotherapy in high-risk patients [22].

\section{Patients and methods}

Inclusion criteria Patients ( $\geq 18$ years old) were recruited at the Centre Pluridisciplinaire d'Oncologie, Lausanne, Switzerland and at the Department of Oncology, University of Basel, Switzerland. All patients gave written informed consent. Histological diagnosis of solid tumours was confirmed in all cases. None of the tumours had been treated previously. All patients were scheduled to receive at least three cycles of platinumbased chemotherapy with minimum doses of $60 \mathrm{mg} / \mathrm{m}^{2}$ cisplatin every 3 weeks or carboplatin $(\mathrm{AUC}=5)$ every 3 weeks. Further requirements included $\mathrm{Hb}$ levels $\geq$ $11 \mathrm{~g} / \mathrm{dL}$, creatinine clearance $\geq 60 \mathrm{ml} / \mathrm{min}$, ECOG performance $\leq 2$ and life expectancy $\geq 3$ months.

Exclusion criteria Patients were excluded from the study if severe co-morbidities or active pulmonary, gastrointestinal and/or genitourinary bleeding were present. Other criteria leading to exclusion from the study were uncontrolled hypertension (diastolic blood pressure $>100 \mathrm{mmHg}$ ); history of seizures; known hypersensitivity to recombinant human erythropoietin or iron (III)-hydroxide sucrose complex; transfusion less than 2 weeks before study entry; acute major illness or infection less than 1 month before study entry; and any previous chemotherapy or radiotherapy.

Treatment with epoetin and dose adjustment Starting on the first day of chemotherapy, $10,000 \mathrm{U}$ epoetin- $\alpha$ were administered subcutaneously three times a week. Patients exhibiting $\mathrm{Hb}$ levels $\geq 13 \mathrm{~g} / \mathrm{dL}$ at baseline were re-examined every 4 weeks and would receive subcutaneous epoetin- $\alpha$ only if $\mathrm{Hb}$ fell under $13 \mathrm{~g} / \mathrm{dL}$. Doses were adjusted every 4 weeks based on $\mathrm{Hb}$ levels. Treatment was temporarily discontinued on reaching the target level of $\geq 13 \mathrm{~g} / \mathrm{dL}$ and was resumed 4 weeks later at the previous dose level if the level once again descended to $<13 \mathrm{~g} / \mathrm{dL}$. In the event that $\mathrm{Hb}$ levels stabilised in the range of $11-13 \mathrm{~g} / \mathrm{dL}$, the dose was reduced from 10,000 to $4,000 \mathrm{U}$, or from 4,000 to $2,000 \mathrm{U}$, over the next 4 weeks. $\mathrm{Hb}$ levels descending to $<11 \mathrm{~g} / \mathrm{dL}$ were handled by increasing the dose to the next higher dose level $(10,000$ to $20,000 \mathrm{U})$ over the next 4 weeks. Epoetin- $\alpha$ was discontinued in patients classified as non-responders.

Epoetin- $\alpha$ was administered throughout the scheduled duration of chemotherapy until 3 weeks after the last injection. The same timetable was used if chemotherapy was prematurely discontinued due to tumour progression or unacceptable toxicity.

Iron was administered intravenously once weekly in the form of iron (III)-hydroxide sucrose complex at a dose level of $100 \mathrm{mg}$ to all patients irrespective of ferritin levels. No additional iron doses were administered once epoetin- $\alpha$ had been discontinued. Erythrocyte transfusions were per- 
formed if $\mathrm{Hb}$ levels dropped below $8 \mathrm{~g} / \mathrm{dL}$; otherwise this option was left to the discretion of the physician in charge.

The protocol was approved by the local ethical committee of the two centres participating in the study.

Assessment of study endpoints The main objective of the study was to prevent anaemia defined as $\mathrm{Hb}<10 \mathrm{~g} / \mathrm{dL}$. A secondary endpoint was to assess the mean weekly dose of epoetin- $\alpha$ administered during chemotherapy treatment. Transfusion requirements were also documented. Complete blood counts were obtained weekly throughout treatment. Ferritin levels were measured at baseline and at the end of treatment. Patients were only evaluated if treatment had been carried on for at least 6 weeks. Resistance to epoetin$\alpha$ was assumed in the presence of persistent $\mathrm{Hb}$ levels of $<10 \mathrm{~g} / \mathrm{dL}$ over 4 weeks of treatment at a dose level of $20,000 \mathrm{U} . \mathrm{Hb}<10 \mathrm{~g} / \mathrm{dL}$ or transfusion was also defined as treatment failure.

Statistical methods The null hypothesis for the primary endpoint would be rejected if the treatment with epoetin- $\alpha$ prevents anaemia $(\mathrm{Hb}<10 \mathrm{~g} / \mathrm{dL})$ in over $70 \%$ of patients compared with $50 \%$ in patients undergoing similar (cisplatin-based) treatment without epoetin- $\alpha$. The sample size required to test this hypothesis was 37 patients (one-sided hypothesis: $\alpha=0.05$; power: $\beta=0.2$ ) according to Fleming [20]. Thus anaemia had to be effectively prevented in over 22 patients for the null hypothesis to be rejected.

\section{Results}

In total, 37 patients were enrolled in the study between April 1999 and September 2002. Pertinent patient characteristics are summarised in Table 1 . The cohort included 26 men and 11 women with a median age of 58 years (range 36-69). The majority of these patients had lung cancer $(n=28)$ and was treated with cisplatin $(n=33)$. Patients were treated with a median number of four cycles of chemotherapy (range 1-6).

At baseline, the median $\mathrm{Hb}$ level was $13.7 \mathrm{~g} / \mathrm{dL}$ (range 10.9-16.2) and median ferritin level was $204 \mu \mathrm{g} / \mathrm{L}$ (range 22-988).

Four patients were excluded from efficacy analysis. Two of them never received epoetin- $\alpha$, one due to treatment refusal after enrolment and another due to chemotherapyrelated haemolysis. The other two patients could not be evaluated because of intercurrent adverse events: one patient died of myocardial infarction on day 16 after having received seven injections of epoetin- $\alpha(\mathrm{Hb}=14.6 \mathrm{~g} / \mathrm{dL})$; and the other patient suffered transient cerebral ischemia on day 7 after having received three injections of epoetin- $\alpha$ $(\mathrm{Hb}=12 \mathrm{~g} / \mathrm{dL})$.

At baseline, 21 of 33 patients (64\%) had $\mathrm{Hb}$ levels $\geq$ $13 \mathrm{~g} / \mathrm{dL}$. Treatment with epoetin- $\alpha$ was initiated after 4 or 8 weeks in all but one of these patients when $\mathrm{Hb}$ levels dropped below $13 \mathrm{~g} / \mathrm{dL}$. Only one patient never required epoetin- $\alpha$. For 12 patients with baseline $\mathrm{Hb}$ level of $11-13 \mathrm{~g} / \mathrm{dL}$, epoetin- $\alpha$ was started concomitantly with the first cycle of chemotherapy.

At the end of therapy, the median $\mathrm{Hb}$ level was down to $11.0 \mathrm{~g} / \mathrm{dL}$ (range 7.4-13.8).

Anaemia with $\mathrm{Hb}<10 \mathrm{~g} / \mathrm{dL}$ was prevented in 24 patients (73\%). Despite epoetin- $\alpha$ treatment, nine patients developed anaemia $(\mathrm{Hb}<10 \mathrm{~g} / \mathrm{dL})$ but all had $\mathrm{Hb} \geq 8 \mathrm{~g} / \mathrm{dL}$.

Treatment failed in nine patients $(27 \%)$. These failures included resistance to epoetin- $\alpha$ in four cases (12\%) despite an increased epoetin- $\alpha$ dose of 20,000 U three times per week, blood transfusion in three cases $(9 \%)$ and premature end of treatment with $\mathrm{Hb}$ level $<10 \mathrm{~g} / \mathrm{dL}$ in two cases $(6 \%)$.

Table 1 Patient characteristics

\footnotetext{
$D D P$ cisplatin, $C B D C A$ carboplatin

${ }^{\text {a }}$ Ovarian carcinoma, unknown primary, urachus carcinoma, neuroendocrine pancreatic carcinoma, mediastinal carcinoma all 1
}

\begin{tabular}{lll}
\hline & All patients & Evaluable patients \\
\hline$N$ & 37 & 33 \\
Men/women & $26 / 11$ & $22 / 11$ \\
PS $\leq 1 / 2$ & $34 / 3$ & $30 / 3$ \\
Median age & $58(36-69)$ & $58(40-68)$ \\
NSCLC & $22(59 \%)$ & $18(56 \%)$ \\
SCLC & $6(16 \%)$ & $6(18 \%)$ \\
Testicular cancer & $2(6 \%)$ & $2(7 \%)$ \\
Bladder carcinoma & $2(6 \%)$ & $2(7 \%)$ \\
Other carcinoma ${ }^{\text {a }}$ & $4(11 \%)$ & $4(12 \%)$ \\
Regimen with DDP $\geq 75 \mathrm{mg} / \mathrm{m}^{2}$ & 33 & 29 \\
Regimen with CBDCA AUC 5 & 4 & 4 \\
Median chemotherapy cycles & 4 cycles $(1-6)$ & 4 cycles $(1-6)$ \\
Median Hb at baseline $(\mathrm{g} / \mathrm{dl})$ & $13.7(10.9-16.2)$ & $13.7(10.9-16.2)$ \\
\hline
\end{tabular}


Epoetin- $\alpha$ was administered for a median of $8(0-20)$ weeks.

Dose levels could be effectively reduced from 10,000 to $4,000 \mathrm{U}$ or less in ten patients $(30 \%)$. Doses were increased to $20,000 \mathrm{U}$ in seven patients $(21 \%)$. The median dose level of epoetin- $\alpha$ used was $5,866 \mathrm{U}$ three times per week.

No adverse events related to the intravenous iron supplements were reported. The median ferritin level was $941 \mu \mathrm{g} / \mathrm{L}$ (range 346-1275) at the end of treatment.

\section{Discussion}

Our data demonstrate that a $30 \%$ reduction of the epoetin- $\alpha$ dose can be achieved in patients with anaemia induced by platinum-based chemotherapy. Anaemia was effectively prevented in 24 of 33 patients (73\%) using the dose-reduction schedule described above. The mean dose requirement of $5,866 \mathrm{U}$ three times per week per patient was $41 \%$ below the recommended standard dose. These findings support current recommendations for a dose decrease to reduce the risk of thrombovascular events associated with ESA's treatment [33].

To our knowledge, this is the first study to explore the lowest epoetin- $\alpha$ dose level that effectively prevents anaemia (defined as $\mathrm{Hb}$ level $<10 \mathrm{~g} / \mathrm{dL}$ ) induced by platinum-based chemotherapy. A previous randomised study included 130 small-cell lung center patients with $\mathrm{Hb}$ levels $>10.5 \mathrm{~g} / \mathrm{dL}$ who were treated three times a week with epoetin- $\alpha 150 \mathrm{U} / \mathrm{kg}(10,000 \mathrm{U})$ or $300 \mathrm{U} / \mathrm{kg}(20,000 \mathrm{U})$ or received no treatment [40]. A total of $66 \%$ of patients in the control group exhibited anaemia $(\mathrm{Hb}<10 \mathrm{~g} / \mathrm{dL})$ compared with $48 \%$ and $39 \%$, respectively, in the two treatment groups. Transfusions were performed in $59 \%, 45 \%$ and $20 \%$ of patients, respectively. Administration of ESA's was temporarily discontinued when $\mathrm{Hb}$ levels reached $>15 \mathrm{~g} / \mathrm{dL}$ and was resumed with the dose reduced by half upon $\mathrm{Hb}$ relapsing to $\leq 13 \mathrm{~g} / \mathrm{dL}$. Thus, the mean weekly doses in the two treatment groups were 335 and $612 \mathrm{U} / \mathrm{kg}$ (equivalent to 7,500 and $13,600 \mathrm{U}$ three times weekly), representing a dose reduction of $25 \%$ and $32 \%$, respectively.

In another randomised trial of epoetin- $\alpha$, a mean dose level of 10,000 U three times weekly prevented anaemia $(\mathrm{Hb}<10 \mathrm{~g} / \mathrm{dL})$ in $83 \%$ of patients, and the transfusion rate was $15 \%$ [5]. The same efficacy was demonstrated with a dose administration of 40,000 U once weekly, which effectively controlled anaemia in $82 \%$ of patients, with $12 \%$ requiring transfusion [15]. Our low transfusion rate $(9 \%)$ is possibly the result of a fairly restrictive transfusion policy. Transfusions were only prescribed when $\mathrm{Hb}$ levels fell to $<8 \mathrm{~g} / \mathrm{dL}$ and were otherwise left to the discretion of the physician in charge. A similar transfusion rate $(8.6 \%)$ was obtained in a randomised study that also evaluated anaemia prevention with similar transfusion guidelines as ours [14]. In that study, weekly doses of 40,000 U epoetin$\alpha$ were decreased by $25 \%$. Doses were withheld when $\mathrm{Hb}$ levels reached $>14 \mathrm{~g} / \mathrm{dL}$ in $29 \%$ of patients or were increased (to $60,000 \mathrm{U}$ ) in $9 \%$ of patients.

The efficacy findings in our trial are similar to those reported in the cited studies despite notably different target $\mathrm{Hb}$ levels and a different general strategy. This demonstrates that the reduction strategy we adopted was not detrimental to achieving target $\mathrm{Hb}$ levels.

One factor that may have contributed to our results was the concomitant weekly intravenous administration of iron. The benefit of parenteral iron had been demonstrated in a number of controlled randomised trials $[4,6,23,41]$. In 157 anaemic cancer patients undergoing chemotherapy, iron supplements to epoetin- $\alpha$, administered either orally at $650 \mathrm{mg} /$ day or intravenously at $100 \mathrm{mg}$ weekly, increased $\mathrm{Hb}$ levels by 1.5 or $2.5 \mathrm{~g} / \mathrm{dL}$, respectively, compared with $0.9 \mathrm{~g} / \mathrm{dL}$ in the placebo group [4].

In our study, two serious vascular events were reported after the initial doses of epoetin- $\alpha$ and were considered unrelated to the study medication by the treating physicians on the basis that the patients' $\mathrm{Hb}$ levels remained within normal range. Indirect toxicity of epoetin- $\alpha$, however, cannot be excluded. These two patients were treated for advanced non-small cell lung cancer and a high rate of cardiovascular events has been documented to occur frequently in this patient population [30]. Although our $\mathrm{Hb}$ target of $13 \mathrm{~g} / \mathrm{dL}$ is higher than current recommendations, the median $\mathrm{Hb}$ level $(11 \mathrm{~g} / \mathrm{dL})$ reached at the end of the treatment period is considered safe.

Our findings and those of the cited studies show that the intensity and thereby the economic burden of ESA's treatment could be substantially decreased if appropriate dose-reduction strategies together with intravenous iron supplements were to be widely adopted. Finally, a dosereduction strategy with stringent rules (target $\mathrm{Hb} \leq 12 \mathrm{~g} / \mathrm{dL}$ ) is also important given the controversially discussed the impact of epoetins on survival $[7,16,32]$.

Acknowledgements We thank Ms. Julia Rengier-Styles for her excellent job in data management and review of the manuscript.

Epoetin-alpha $\left(\right.$ Eprex $\left.^{\circledR}\right)$ was provided by Janssen-Cilag Company. Iron (III)-hydroxide sucrose complex was provided by Vifor AG Company.

The sponsors had no role in the study design, the collection and interpretation of data, the writing of the manuscript, or the decision to submit the manuscript for publication.

Conflict of interest statement None of the authors has any financial or potential conflict of interest to disclose.

\section{References}

1. The NCCN Cancer- and Chemotherapy-Induced Anemia Clinical Practice Guideline in Oncology (Version 3.2009).C 2008 National Comprehensive Cancer Network, Inc. Available at: http://www.ncen. 
org. Accessed [November 18, 2008]. To view the most recent and complete version of the guideline, go online to www.ncen.org

2. Aapro MS, Link H (2008) September 2007 update on EORTC guidelines and anemia management with erythropoiesisstimulating agents. Oncologist 13(Suppl 3):33-36

3. Arcasoy MO (2008) The non-haematopoietic biological effects of erythropoietin. Br J Haematol 141:14-31

4. Auerbach M, Ballard H, Trout JR, Mcllwain M, Ackerman A, Bahrain H, Balan S, Barker L, Rana J (2004) Intravenous iron optimizes the response to recombinant human erythropoietin in cancer patients with chemotherapy-related anemia: a multicenter, open-label, randomized trial. J Clin Oncol 22:1301-1307

5. Bamias A, Aravantinos G, Kalofonos C, Timotheadou N, Siafaka V, Vlahou I, Janinis D, Pectasides D, Pavlidis N, Fountzilas G (2003) Prevention of anemia in patients with solid tumors receiving platinum-based chemotherapy by recombinant human Erythropoietin (rHuEpo): a prospective, open label, randomized trial by the Hellenic Cooperative Oncology Group. Oncology 64:102-110

6. Bastit L, Vandebroek A, Altintas S, Gaede B, Pinter T, Suto TS, Mossman TW, Smith KE, Vansteenkiste JF (2008) Randomized, multicenter, controlled trial comparing the efficacy and safety of darbepoetin alpha administered every 3 weeks with or without intravenous iron in patients with chemotherapy-induced anemia. J Clin Oncol 26:1611-1618

7. Bennett CL, Silver SM, Djulbegovic B, Samaras AT, Blau CA, Gleason KJ, Barnato SE, Elverman KM, Courtney DM, McKoy JM, Edwards BJ, Tigue CC, Raisch DW, Yarnold PR, Dorr DA, Kuzel TM, Tallman MS, Trifilio SM, West DP, Lai SY, Henke M (2008) Venous thromboembolism and mortality associated with recombinant erythropoietin and darbepoetin administration for the treatment of cancer-associated anemia. JAMA 299:914-924

8. Bohlius J, Langensiepen S, Schwarzer G, Seidenfeld J, Piper M, Bennett C, Engert A (2005) Recombinant human erythropoietin and overall survival in cancer patients: results of a comprehensive meta-analysis. J Natl Cancer Inst 97:489-498

9. Bohlius J, Schmidlin K, Brillant C, Schwarzer G, Trelle S, Seidenfeld J, Zwahlen M, Clarke M, Weingart O, Kluge S, Piper M, Rades D, Steensma DP, Djulbegovic B, Fey MF, Ray-Coquard I, Machtay M, Moebus V, Thomas G, Untch M, Schumacher M, Egger M, Engert A (2009) Recombinant human erythropoiesisstimulating agents and mortality in patients with cancer: a metaanalysis of randomised trials. Lancet 373:1532-1542

10. Bohlius J, Wilson J, Seidenfeld J, Piper M, Schwarzer G, Sandercock J, Trelle S, Weingart O, Bayliss S, Djulbegovic B, Bennett CL, Langensiepen S, Hyde C, Engert A (2006) Recombinant human erythropoietins and cancer patients: updated meta-analysis of 57 studies including 9353 patients. J Natl Cancer Inst 98:708-714

11. Bokemeyer C, Aapro MS, Courdi A, Foubert J, Link H, Osterborg A, Repetto L, Soubeyran P (2007) EORTC guidelines for the use of erythropoietic proteins in anaemic patients with cancer: 2006 update. Eur J Cancer 43:258-270

12. Caro JJ, Salas M, Ward A, Goss G (2001) Anemia as an independent prognostic factor for survival in patients with cancer: a systemic, quantitative review. Cancer 91:2214-2221

13. Cascinu S, Fedeli A, Del Ferro E, Luzi Fedeli S, Catalano G (1994) Recombinant human erythropoietin treatment in cisplatinassociated anemia: a randomized, double-blind trial with placebo. J Clin Oncol 12:1058-1062

14. Chang J, Couture F, Young S, McWatters KL, Lau CY (2005) Weekly epoetin alfa maintains hemoglobin, improves quality of life, and reduces transfusion in breast cancer patients receiving chemotherapy. J Clin Oncol 23:2597-2605

15. Crawford J, Robert F, Perry M, Belani CP, Sarokhan B, for the Anemia Prevention in NSCLC Study Group (2003) Epoetin alfa
40,000 $\mathrm{U}$ once weekly maintains hemoglobin in advanced nonsmall-cell lung cancer patients receiving first-line chemotherapy. Proc Am Soc Clin Oncol 22:abstract 2527

16. Crawford J (2007) Erythropoietin: high profile, high scrutiny. J Clin Oncol 25:1021-1023

17. Crawford J, Robert F, Perry MC, Belani C, Williams D (2007) A randomized trial comparing immediate versus delayed treatment of anemia with once-weekly epoetin alfa in patients with nonsmall cell lung cancer scheduled to receive first-line chemotherapy. J Thorac Oncol 2:210-220

18. de Castro J, Belda-Iniesta C, Isla D, Domine M, Sanchez A, Batiste E, Baron MG (2008) Early intervention with epoetin beta prevents severe anaemia in lung cancer patients receiving platinum-based chemotherapy: a subgroup analysis of the NeoPrevent study. Lung Cancer 59:211-218

19. Duh MS, Weiner JR, White LA, Lefebvre P, Greenberg PE (2008) Management of anaemia: a critical and systematic review of the cost effectiveness of erythropoiesis-stimulating agents. Pharmacoeconomics 26:99-120

20. Fleming TR (1982) One-sample multiple testing procedure for phase II clinical trials. Biometrics 38:143-151

21. Glaspy J, Bukowski R, Steinberg D, Taylor C, Tchekmedyian S, Vadhan-Raj S (1997) Impact of therapy with epoetin alfa on clinical outcomes in patients with nonmyeloid malignancies during cancer chemotherapy in community oncology practice. Procrit Study Group J Clin Oncol 15:1218-1234

22. Groopman JE, Itri LM (1999) Chemotherapy-induced anemia in adults: incidence and treatment. J Natl Cancer Inst 91:1616-1634

23. Hedenus M, Birgegard G, Nasman P, Ahlberg L, Karlsson T, Lauri B, Lundin J, Larfars G, Osterborg A (2007) Addition of intravenous iron to epoetin beta increases hemoglobin response and decreases epoetin dose requirement in anemic patients with lymphoproliferative malignancies: a randomized multicenter study. Leukemia 21:627-632

24. Henke M, Mattern D, Pepe M, Bezay C, Weissenberger C, Werner M, Pajonk F (2006) Do erythropoietin receptors on cancer cells explain unexpected clinical findings? J Clin Oncol 24:4708-4713

25. Jelkmann W, Bohlius J, Hallek M, Sytkowski AJ (2008) The erythropoietin receptor in normal and cancer tissues. Crit Rev Oncol Hematol 67:39-61

26. Kimel M, Leidy NK, Mannix S, Dixon J (2008) Does epoetin alfa improve health-related quality of life in chronically ill patients with anemia? Summary of trials of cancer, HIV/AIDS, and chronic kidney disease. Value Health 11:57-75

27. Littlewood TJ, Bajetta E, Nortier JW, Vercammen E (2001) Effects of epoetin alfa on hematologic parameters and quality of life in cancer patients receiving nonplatinum chemotherapy: results of a randomized, double-blind, placebo-controlled trial. J Clin Oncol 19:2865-2874

28. Ludwig H, Van Belle S, Barrett-Lee P, Birgegard G, Bokemeyer C, Gascon P, Kosmidis P, Krzakowski M, Nortier J, Olmi P, Schneider M, Schrijvers D (2004) The European Cancer Anaemia Survey (ECAS): a large, multinational, prospective survey defining the prevalence, incidence, and treatment of anaemia in cancer patients. Eur J Cancer 40:2293-2306

29. Marchetti M, Barosi G (2004) Clinical and economic impact of epoetins in cancer care. Pharmacoeconomics 22:1029-1045

30. Numico G, Garrone O, Dongiovanni V, Silvestris N, Colantonio I, Di Costanzo G, Granetto C, Occelli M, Fea E, Heouaine A, Gasco M, Merlano M (2005) Prospective evaluation of major vascular events in patients with nonsmall cell lung carcinoma treated with cisplatin and gemcitabine. Cancer 103:994-999

31. Pedrazzoli P, Farris A, Del Prete S, Del Gaizo F, Ferrari D, Bianchessi C, Colucci G, Desogus A, Gamucci T, Pappalardo A, Fornarini G, Pozzi P, Fabi A, Labianca R, Di Costanzo F, Secondino S, Crucitta E, Apolloni F, Del Santo A, Siena S 
(2008) Randomized trial of intravenous iron supplementation in patients with chemotherapy-related anemia without iron deficiency treated with darbepoetin alpha. J Clin Oncol 26:1619-1625

32. Pirker R, Ramlau RA, Schuette W, Zatloukal P, Ferreira I, Lillie T, Vansteenkiste JF (2008) Safety and efficacy of darbepoetin alpha in previously untreated extensive-stage small-cell lung cancer treated with platinum plus etoposide. J Clin Oncol 26:2342-2349

33. Rizzo JD, Somerfield MR, Hagerty KL, Seidenfeld J, Bohlius J, Bennett CL, Cella DF, Djulbegovic B, Goode MJ, Jakubowski AA, Rarick MU, Regan DH, Lichtin AE (2008) Use of epoetin and darbepoetin in patients with cancer: 2007 American Society of Clinical Oncology/American Society of Hematology clinical practice guideline update. J Clin Oncol 26:132-149

34. Schouwink JH, Codrington H, Sleeboom HP, Kerkhofs LG, Wormhoudt LW (2008) Prevention of anaemia by early intervention with once weekly epoetin alfa during chemotherapy. Eur J Cancer 44:819-829

35. Scrijvers D, Roila F (2009) Erythropoiesis-stimulating agents in cancer patients: ESMO recommendations for use. Ann Oncol 20 (Suppl 4):159-161

36. Seidenfeld J, Piper M, Flamm C, Hasselblad V, Armitage JO, Bennett CL, Gordon MS, Lichtin AE, Wade JL 3rd, Woolf S, Aronson N (2001) Epoetin treatment of anemia associated with cancer therapy: a systematic review and meta-analysis of controlled clinical trials. J Natl Cancer Inst 93:1204-1214

37. Steensma DP, Molina R, Sloan JA, Nikcevich DA, Schaefer PL, Rowland KM Jr, Dentchev T, Novotny PJ, Tschetter LK, Alberts SR, Hogan TF, Law A, Loprinzi CL (2006) Phase III study of two different dosing schedules of erythropoietin in anemic patients with cancer. J Clin Oncol 24:1079-1089
38. Stohlawetz PJ, Dzirlo L, Hergovich N, Lackner E, Mensik C, Eichler HG, Kabrna E, Geissler K, Jilma B (2000) Effects of erythropoietin on platelet reactivity and thrombopoiesis in humans. Blood 95:2983-2989

39. Straus DJ, Testa MA, Sarokhan BJ, Czuczman MS, Tulpule A, Turner RR, Riggs SA (2006) Quality-of-life and health benefits of early treatment of mild anemia: a randomized trial of epoetin alfa in patients receiving chemotherapy for hematologic malignancies. Cancer 107:1909-1917

40. Thatcher N, De Campos ES, Bell DR, Steward WP, Varghese G, Morant R, Vansteenkiste JF, Rosso R, Ewers SB, Sundal E, Schatzmann E, Stocker H (1999) Epoetin alpha prevents anaemia and reduces transfusion requirements in patients undergoing primarily platinum-based chemotherapy for small cell lung cancer. Br J Cancer 80:396-402

41. Vandebroek A (2006) A randomized open-label study of darbepoetin alfa administered every 3 weeks with or without parenteral iron in anemic subjects with nonmyeloid malignancies receiving chemotherapy. In: A randomized open-label study of darbepoetin alfa administered every 3 weeks with or without parenteral iron in anemic subjects with nonmyeloid malignancies receiving chemotherapy

42. Wilson J, Yao GL, Raftery J, Bohlius J, Brunskill S, Sandercock J, Bayliss S, Moss P, Stanworth S, Hyde C (2007) A systematic review and economic evaluation of epoetin alpha, epoetin beta and darbepoetin alpha in anaemia associated with cancer, especially that attributable to cancer treatment. Health Technol Assess 11:1-202, iii-iv

43. Witzig TE, Silberstein PT, Loprinzi CL, Sloan JA, Novotny PJ, Mailliard JA, Rowland KM, Alberts SR, Krook JE, Levitt R, Morton RF (2005) Phase III, randomized, double-blind study of epoetin alfa compared with placebo in anemic patients receiving chemotherapy. J Clin Oncol 23:2606-2617 